\title{
Persistent Fistula after Sleeve Gastrectomy: A Chronic Dilemma
}

\author{
Cristian E. Boru, Francesco de Angelis, Angelo lossa, Pavlos Antypas, Chiara Ciccioriccio, Pietro Termine, \\ Gianfranco Silecchia
}

University La Sapienza of Rome, Department of Medico-Surgical Sciences and Biotechnologies, Division of General Surgery \& Bariatric Centre of Excellence-IFSO EC, Italy

Corresponding author:

Cristian E. Boru, MD

University La Sapienza of Rome

Polo Pontino

Division of General Surgery \&

Bariatric Center of Excellence-IFSO

EC, AUSL LT-ICOT

Via F. Faggiana 1668, Latina, Italy

Tel 003907736513374

Fax 003907736513333

E-mail:drcrisb@gmail.com

\section{Abbreviations:}

LSG - Laparoscopic sleeve gastrectomy; GEJ - gastroesophageal junction; GBPF - esogastro-pleural fistulas; GCF - gastro-cutaneous fistulas; TEN - total enteral nutrition.

\section{Rezumat}

Fistula persistentă după sleeve gastrectomy: o dilemă cronică

Nu există limită de timp în ceea ce priveşte apariția fistulelor după sleeve gastrectomy LSG, iar cele cu debut tardiv pot evolua către fistule persistente, cronice. Scopul acestui studiu retrospectiv a fost de a analiza incidența, tratamentul şi urmările după acestea, tratate într-un Centru de Excelență de chirurgie bariatrică şi de a dezvolta un tratament standard.

Materiale şi Metode: între 2011-2018, 9 cazuri de fistule postoperatorii au apărut după un număr total de 1365 LSG (0,65\%), 7 prezentând debut tardiv (minim 10 zile de la operație). Au fost identificate şi analizate fistulele cronice, persistente, inclusiv o fistulă gastro-bronhială şi una gastro-cutanată.

Rezultate: prezentăm 3 cazuri particulare de fistule foarte tardive, cronice de tip III (fistule complexe), cu debut variind de la 6 până la 84 luni după LSG, şi tratamentul acestora (conservativ, radiologie şi/sau endoscopie intervențională, chirurgical).

Concluzii: managementul fistulelor tardive, cronice de tip III, este variabil, nestandardizat şi ar trebui planificat pe baza evoluției clinice, momentul diagnosticului, resursele disponibile şi expertiza locală. Un centru bariatric de excelență poate garanta un diagnostic şi tratament mai adecvat, pe baza resurselor şi a posibilităților existente.

Cuvinte cheie: fistula cronică, sleeve gastrectomy, fistula complexă tip III, gastro-bronhică, gastro-cutanată 


\begin{abstract}
Background: There is no time limit for the occurrence of leaks after sleeve gastrectomy LSG, and very late ones might evolve versus persistent, chronic fistulas. The aim of this retrospective study was to analyze the incidence, treatment and outcomes of persistent, chronic fistulas occurred or treated in a bariatric Center of Excellence IFSO-EC (CoE) and to establish a standardized approach. Materials \& Methods: between 2011-2018, nine cases of postoperative leaks occurred on a total of 1365 LSG performed (0.65\%), 7 of them having late presentations (onset over 10 days postoperative). Chronic, persistent fistulas were identified and analyzed, including one gastro-bronchial and one gastro-cutaneous fistulas.

Results: We present three peculiar cases of very late, chronic type III fistulas, with onset at 6-84 months after primary LSG and their management, including conservative, interventional radiology and endoscopy and surgical therapies.

Conclusions: the management of late, chronic type III fistula is variable, with no standard algorithm to follow, but it should be planned based on the clinical evaluation, time of diagnosis, available resources, multidisciplinary approach and expertise. This emphasises again the necessity of a bariatric $\mathrm{CoE}$ that can guarantee a better diagnose and treatment, based on the use of wide, available resources, both professional and material.
\end{abstract}

Key words: chronic fistula, sleeve gastrectomy, type III fistulas, gastro-bronchial, gastro-cutaneous

\section{Introduction}

Laparoscopic sleeve gastrectomy (LSG) seems to be the most popular bariatric surgery procedure in the US and in Europe (1). Gastric leak is still the most dreaded complication, with a mean incidence of $2.1 \%(1.1-5.3 \%)(2)$, even if more and more therapeutically modalities have been developed in the recent decade, especially endoscopic (3). A leak mainly occurs under the gastroesophageal junction (GEJ) and more rarely at the middle part of the staple line, and the causes, even if not very clear, can be mechanical or vascular, as intraluminal hyper pressure and changes in blood supply may influence. Additional factors that may contribute are diabetes, infections, age over 55 years, blood hypertension, revisional surgery, BMI $>50 \mathrm{~kg} / \mathrm{m}^{2}$, obstructive sleep apnea syndrome OSAS and heavy smoking $(4,5)$. According to the time of onset, gastric leaks are classified as early when appearing within the first four postoperative days, intermediate when appearing in postoperative days $5-9$ and late when occurring in or after the tenth post-operative day (6).
Persistent leak could become a fistula, that represent an abnormal communication between two epithelialized surfaces. The gastric fistulas are classified in 3 anatomical types: type I a small leak with no collection; type II leak with associated abdominal abscess; type III a leak with multiple internal or external abscesses. The CT scan with double contrast (intravenous and oral) represents the best method to identify and correctly classify gastric fistulas (7). The literature is lacking on reports about complex chronic gastric fistula's (> 3 months evolution) management. Chronic gastric fistula can progress to complex anatomical situations, such as esogastrobronchial and/or esogastro-pleural fistulas (GBPF), as well as gastro-cutaneous (GCF) or gastro-colic fistulas (8). Usually, in noncomplicated patients the management include a non-operative treatment (interventional radiology, endoscopic and medical treatment) with encouraging results (resolution rate up to 83.4\%) (3). However, type III fistula represents a challenge for the treatment and requires a critical decision-making in the absence of a standardized protocol. 


\section{Aims}

The aim of the present study was to retrospectively analyze the incidence, treatment and outcomes of very late leaks after LSG, evolved in persistent, chronic fistulas occurred or treated in our bariatric Center of Excellence IFSO-EC (CoE) and to establish a standardized approach based on a multidisciplinary team.

\section{Materials and Methods}

Between 2011-2018, in our CoE a total of 1746 bariatric procedures were performed, from which 1365 were LSGs (78\%). Nine patients developed postoperative leaks (0.65\%), 7 of them having late presentations onset (over 10 days postoperative). We present a single center's experience of three peculiar cases of very late, chronic type III fistulas with onset at least 6 months after initial, primary LSG and their management; in 2 cases the LSG was performed in our $\mathrm{CoE}$, the third one was referred to us.

\section{Results}

\section{Case 1}

A 39-year-old female, presenting with morbid obesity (BMI $41.6 \mathrm{~kg} / \mathrm{m}^{2}$ ) was submitted to LSG in our CoE in 2015, with uneventful short-term postoperative course. Seven months later, the patient was readmitted to our center with fever of $38^{\circ} \mathrm{C}$, moderate leukocytosis (WBC $13 \times 10^{3}$ $/ \mathrm{uL}$ ), high C-reactive protein (CRP $32 \mathrm{mg} / \mathrm{dL}$ ) and left upper abdominal pain. CT scan revealed a $42 \times 15 \mathrm{~mm}$ abscess with air-fluid level along the staple line border $3 \mathrm{~cm}$ under the GEJ together with a small $1.1 \mathrm{~cm}$ fistula confirmed by endoscopy. A conservative management was adopted, with total enteral nutrition (TEN) on naso-enteral tube (Nutrison 2295 Kcal per day) and empirical antibiotics therapy (piperacillin / tazobactam 4.5 grams every 6 hours). The antibiotic treatment was stopped 15 days later, when inflammatory markers were in resolution $\left(\mathrm{WBC}=8.3 \times 10^{3} / \mathrm{uL}\right.$; $\mathrm{CRP}=1.2 \mathrm{mg} / \mathrm{dL}$ ). 45 days later an endoscopic clip (Instinct ${ }^{\mathrm{TM}}$ Clip, Cook Medical Winston-
Salem, NC, USA) was placed and a regular diet restored. Six months later, a CT scan and endoscopy showed a healed leak. 18 months after LSG and 12 months after leak onset, she showed excellent weight loss (EWL\% 72) and no clinical/radiological signs of leak recurrence. A summary of treatment is highlighted: 70 days therapy (15 days under antibiotics), 45 fasting days and TEN, 3 endoscopies from which 1 operative (9).

\section{Case 2}

44 years old man with a history of LSG in 2011 for obesity (BMI $49.4 \mathrm{~kg} / \mathrm{m}^{2}$ ) performed in another bariatric center, with no other comorbidities in his clinical history, except tobacco addiction (40 cigarettes/daily). He had a good weight loss and the post-operative follow-up was uneventful. Seven years later, in September 2018 he was admitted to the local emergency department for acute respiratory distress. During the hospital stay a pneumonia with a left hydropneumothorax was diagnosed. The patient underwent a left thorax drain placement and antibiotherapy till clinical resolution was obtained. Unfortunately, the patient continued to present respiratory distress after the hospital discharge and had several, sequential hospitalizations during the following months. In December 2018 the patient underwent a total body CT-scan with double contrast which diagnosed a gastro-bronchial fistula with an associated medio-gastric stenosis, and for that reason the patient was referred to our bariatric CoE. We decided to treat the patient conservatively using multiple strategies: in January 2019 the patient underwent upper GI endoscopy, and during the procedure one over the scope clip (OTSC ${ }^{\circledR}$ System, Ovesco Endoscopy AG, Germany) was placed to close the fistula orifice and concomitantly a $20 \mathrm{~cm}$ self-expanding metal stent (SEMS) were placed (Beta Stent ${ }^{\mathrm{TM}}$, Taewoong Medical, Korea, $22 \mathrm{Fr}$ ) to cover the fistula and treating the stenosis. The stent was removed 15 days later, and an endoscopic dilatation was performed. The upper GI contrast series 
performed during the procedure didn't show leakage of the oral contrast. During the next period, the patient underwent a control CT scan which demonstrated the persistence of gastro-bronchial fistula. This evidence suggested to place another SEMS and a feeding jejunostomy (March 2019, see Figs. 1, 2). Despite of the good clinical condition (no fever, normal blood exams and no respiratory symptoms) the imaging didn't show any improvement after this therapy, so for that reason it was decided to place endoscopically a double pigtail internal drainage in May 2019. Following this, the patient was discharge with enteral feeding and no antibiotherapy. The follow-up was uneventful, but the control CT-scan performed in June and in July 2019 demonstrated the persistence of the gastrobronchial fistula associated with a perigastric collection.
The patient was readmitted to our hospital (July 2019) and in August 2019 an explorative laparoscopy was performed, which demonstrate the medio-gastric stenosis of the sleeve that we decide to treat with omega by-pass above the stenosis. The upper part of the sleeve and the left diaphragmatic pillar were wrapped by inflammatory tissue and fibrosis. During the exploration of this area, the pseudocavity in communication with the fistula was opened, but this caused hypercapnia and for that reason the procedure was stopped. During the next post-operative follow-up, the patient complained cough, respiratory distress, and a large amount of sputum with biliary characteristics. Two weeks after surgery a naso-bronchial tube was placed in interventional radiology and later another OTSC Ovesco clip and a $20 \mathrm{~cm}$ SEMS were placed in interventional endoscopy (Beta

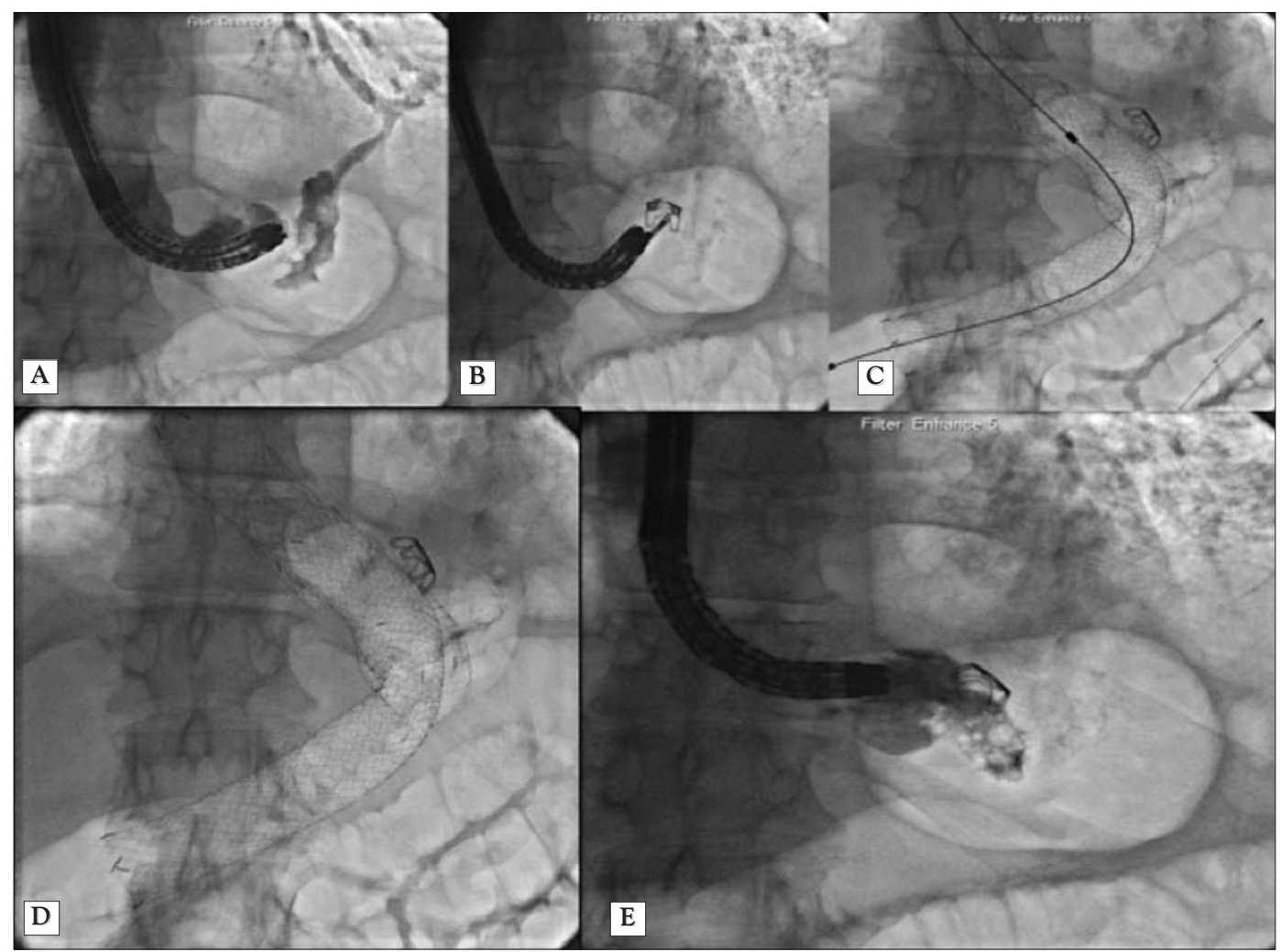

Figure 1. (A) Radiologic appearance, after endoscopic contrast's injection, of a late gastro-bronchial fistula after sleeve gastrectomy; (B) OTSC® Clip System (Ovesco Endoscopy AG, Germany) positioning; (C, D) Fully covered metallic stent positioning; (E) Control after 5 weeks with still extravasation of contrast medium 


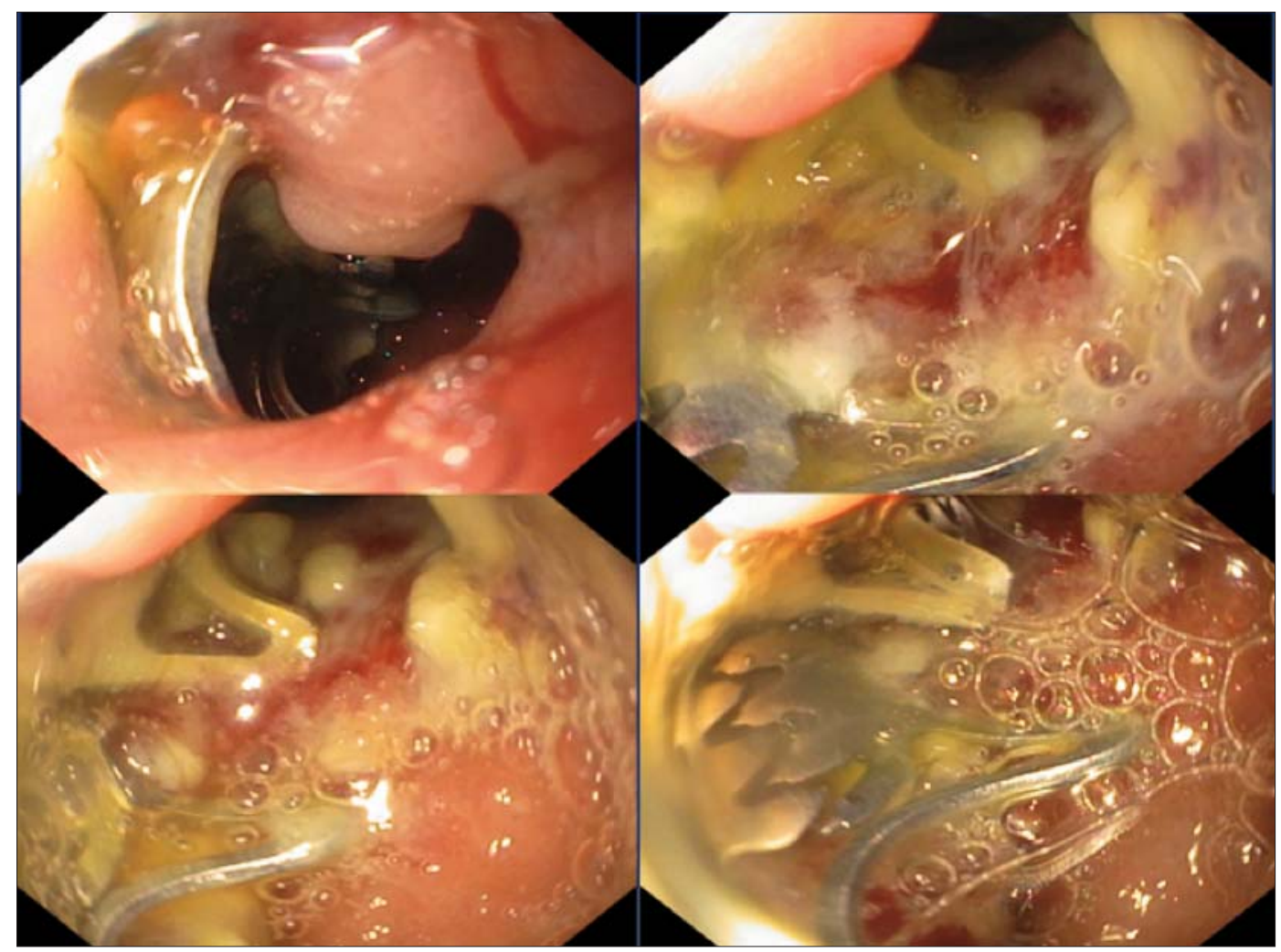

Figure 2. Residual late gastro-bronchial fistula orifice after 2 OTSC $®$ Clip System previous placement. One of the clips has completely dislocated and fallen into the gastric lumen

Stent ${ }^{\text {TM }}$, Taewoong Medical, Korea, 22 Fr). The patient experienced symptoms resolution associated with an improvement of the perigastric collection, as demonstrated by control CT scan. The next step was the thoracic surgery consult, but surgical procedure with left inferior lobectomy was contraindicated due to the high risk of septic complications.

In September 2019 the stent was removed, while the patient presented good clinical condition with cough and dyspnea resolution, even if during the endoprosthesis' removal the fall of the clip and persistence of fistula were documented. In October 2019 the CT scan confirmed the gastro-bronchial fistula with a complete resolution of the perigastric collection. Considering the high operative risks of an eventual inferior lobectomy associated with a total gastrectomy with an Ivor-Lewis reconstruction, we decided to treat the patient with the endoscopic application of autologous stem cell gel through the gastric orifice of the fistula and from the bronchial side by bronchoscopy. The patient underwent already 2 applications in November and actually is in follow-up with a good symptoms' resolution and no signs of gastro-bronchial communication. Longer term follow-up is still needed in this complicated case for definitive resolution.

\section{Case 3}

A 44 years old male, heavy smoker, affected by class III obesity (BMI $43.4 \mathrm{~kg} / \mathrm{m}^{2}$ ) complicated by hypertension, OSAS, dyslipidemia and liver steatosis, was submitted to LSG in February 2016 in our CoE. The postoperative course was uneventful, and he was discharged in the second p.o. day. The patient attended the scheduled follow-up (7 and 30 days) showing an initial good weight loss $(-24 \mathrm{~kg})$. Almost six months later he was admitted to the emergency unit of a different hospital for high fever $\left(39^{\circ} \mathrm{C}\right)$ and persistent cough. The 
chest CT-scan diagnosed an inferior left lobe pneumonia. The patient was treated with antibiotics therapy and discharge after 10 days. Two months after (September 2016), he was referred to our CoE for a similar episode. The clinical examination was unremarkable to any sign of intraabdominal infection. The CT scan with double contrast (oral and intravenous) demonstrated an abscess (31 x 17 $\mathrm{mm}$ ) between stomach, left diaphragm and lung without leak's evidence, while the endoscopy showed a small gastric fistula (7 $\mathrm{mm}), 1 \mathrm{~cm}$ under the GEJ. Considering the time frame ( 7 months after LSG) and the clinical status, a non-operative treatment was started, including: fasting, TEN through nasojejunal tube and empirical antibiotics therapy (meropenem $1000 \mathrm{mg}$ per day for 15 days). Forty-five days later, the abscess was solved (as demonstrated by CT-scan re-evaluation) and an endo-clip (Quick Clip Pro ${ }^{\mathrm{TM}}$, Olympus, Tokyo, Japan) was applied over a persistent fistula of $3 \mathrm{~mm}$ diameter. One year later the patient was re-evaluated by CT-scan for recurrent hiccough with rare episodes of night fever (normal WBC and CRP, BMI $26.2 \mathrm{~kg} /$ $\mathrm{m}^{2}$ ), that showed a $2 \mathrm{~mm}$ fistula, confirmed by the endoscopy, and another endo-clip was placed (Quick Clip Pro ${ }^{\mathrm{TM}}$ ). After fifteen days the fistula appeared healed on endoscopy and two months later a CT-scan confirmed the fistula's resolution (February 2017, 1 year after the LSG). The patient returned to his normal activity and participate to p.o. nutritional follow-up, without any remarkable symptoms. In August 2018 the patient was admitted to the emergency unit of a different hospital for abdominal pain associated with high fever and left paraumbilical abscess. The treatment consisted in abscess drainage and antibiotherapy and he was discharge 20 days later with resolution of symptoms. Five months after, due to recurrent symptoms, the patient was readmitted in the same hospital where, for a gastrocutaneous fistula diagnosed by X-ray swallow, chest and abdomen CT-scan and endoscopy, was referred to our Center (Fig. 3). Patient was treated with multiple approaches: March 2019 over the scope clip

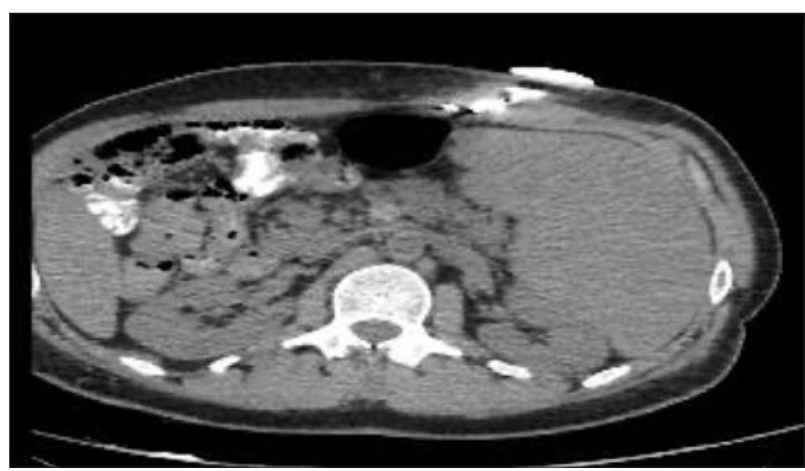

Figure 3. CT-scan fistulography showing gastro-cutaneous communication after late fistula post LSG

(OTSC $\AA$ System, Ovesco Endoscopy AG, Germany) and SEMS (Beta Stent ${ }^{\text {TM }}$, Taewoong Medical, Korea, 22 Fr, $24 \mathrm{~mm}$ x $100 \mathrm{~mm}$ ). (Fig. 4A); April 2019 percutaneous $10 \mathrm{Fr}$ pig tail (Fig. 4B); July 2019 laparoscopic feeding jejunostomy and glue injection in fistulas tract; September 2019 second SEMS.
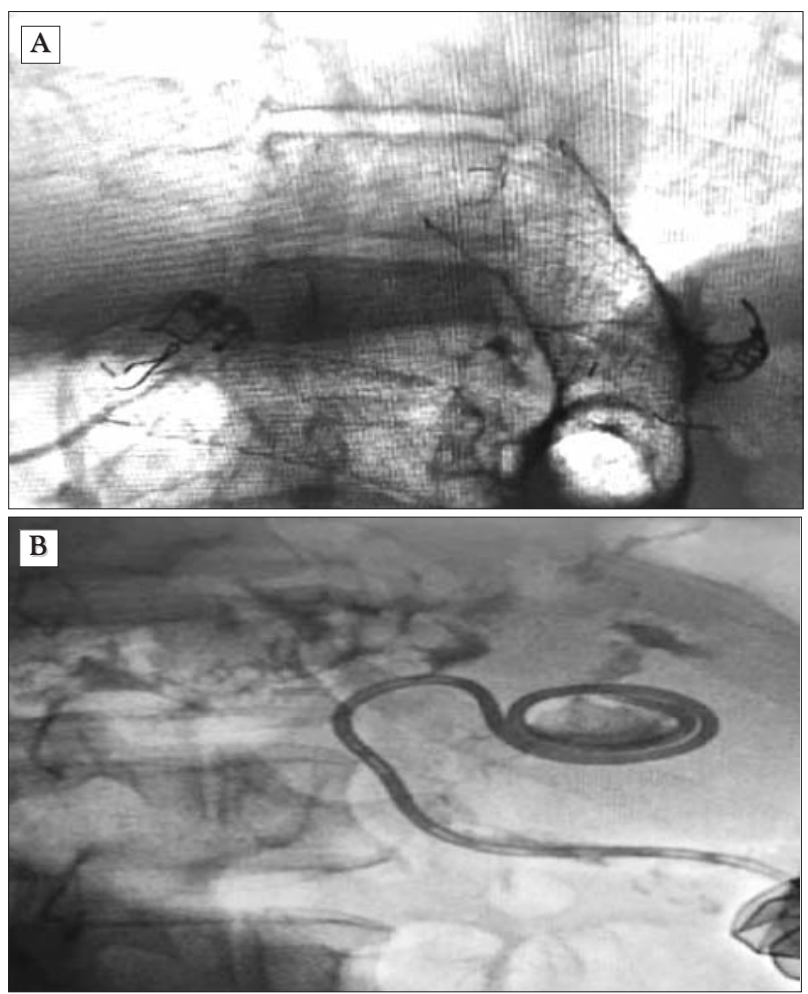

Figure 4. (A) OTSC $®$ Clip (Ovesco Endoscopy AG, Germany) and self-expanding metal stent (Beta Stent ${ }^{\mathrm{TM}}$, Taewoong Medical, Korea, 22 Fr) positioning.

(B) Percutaneous $10 \mathrm{Fr}$ pig tail drainage. 
Unfortunately, all these treatments were unsuccessful after 36 months of therapy, and after accurate informed consensus was obtained, the patient was candidate to laparoscopic total gastrectomy with R-en-Y reconstruction (October 2019). The operation was completed laparoscopically in 250 minutes and the p.o. course uneventful. The patient was discharge in the 7th p.o. day, after normal $\mathrm{X}$-ray control and the 30-days follow-up showed a good physical and nutritional recovery, with normal X-ray contrast study (Fig. 5).

\section{Discussion}

Complex fistulas like gastro-cutaneous (GCF) or esogastro-bronchial (EGBF) are rare but complex type of post-sleeve gastrectomy fistulas, with no standardized or typical treatment and represent a potentially catastrophic complication, with very high long-term mortality rate when proper treatment measures are not engaged. They are

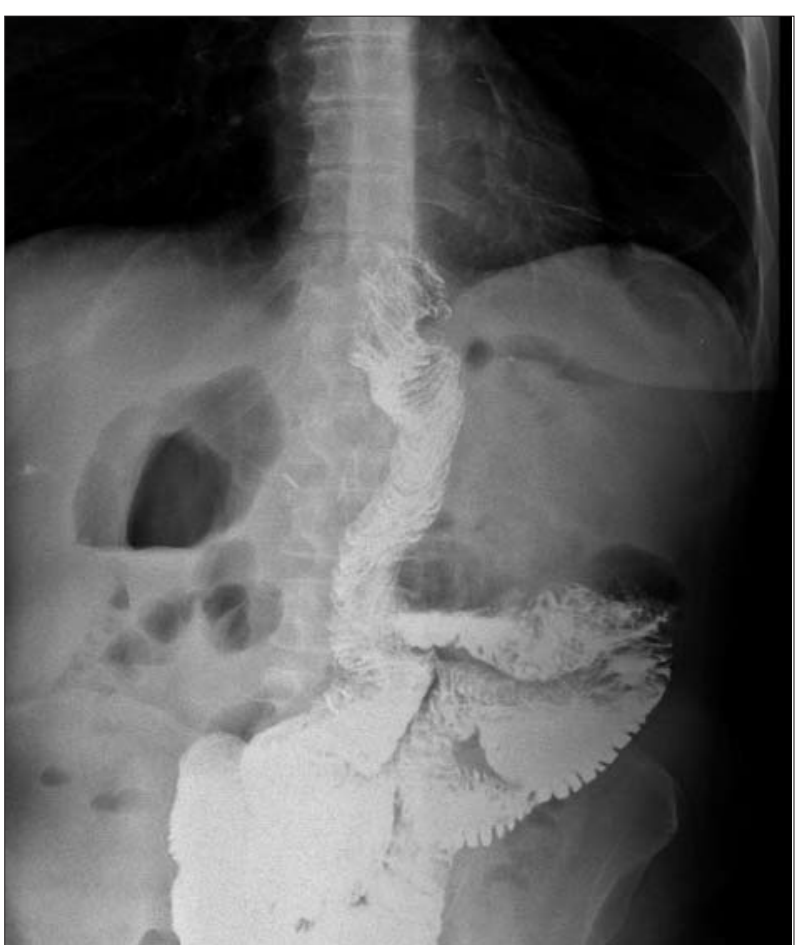

Figure 5. Contrast $\mathrm{X}$-ray control 30 days after total gastrectomy with R-en-Y reconstruction for late, persistent, chronic fistula after LSG, showing no extravasations secondary complication of staple line leak and probably result from delayed or inappropriate diagnosis and treatment, early in the disease course. The true worldwide incidence is not known, but it is probably underreported, ranging from $0.2 \%$ up to $0.37 \%$ (10). Inadequate initial drainage may lead to subsequent subphrenic abscess formation and trans-diaphragmatic fistulization into the pleural cavity or the distal bronchus of the left lung basal segments in case of EGBF or gastrocutaneous communication in case of GCF. Primary measures include NPO, TPN or TEN, antibiotherapy, nasogastric tube and laparoscopic or CT-guided drainage. Secondline procedures may include SEMS, endo-clip or endo-ring closure, internal drainage, argon plasma ablation, endo-vac and glue injection. Endo-treatment is always a good primary choice and might replace surgical solutions, like in our second case. Unfortunately, endoscopic treatment does not carry a $100 \%$ success rate, with reports of up to $69 \%$ of the gastrobronchial fistulas requiring complementary surgical treatment following primary endoscopic treatment (11). Eventually, surgical solution is burdened by a high mortality and morbidity, with usually open, complex techniques including total gastrectomy, R-en$\mathrm{Y}$ reconstruction, pulmonary lobectomy, pleural drainage or even combinations of this.

\section{Conclusion}

In conclusion, the management of late, chronic type III fistula has no standardized algorithm, but it should be based on the clinical evolution, timing, available resources, multidisciplinary approach and expertise. Leaks after bariatric surgery can occur anytime in the postoperative course, with reports of events even 38 years later. We presented 3 different cases of very late leaks, evolving in complex, type III fistulas. First case presented complete resolution under interventional endoscopy treatment, but this case was immediately diagnosed in our $\mathrm{CoE}$, and treated intensely for almost 3 months. Second case, with gastric leak clinically presented 7 years after the 
LSG, required not only intense conservative treatment, but as well combined, multidisciplinary approaches, with multiple endoscopic and radiological sessions and surgical intervention, and the final, positive result is still to be confirmed; while the third case, even after highly specialized, complex endoscopic and radiological approaches, only the aggressive and definitive surgical solution resolved the 3 years evolution of the chronic, complicated fistula. The importance of our study results not only from the complexity of the cases and their management, but in the highlighting of the compulsory, available multidisciplinary resources involved. The limitations are of course the type of the study, retrospective, and the small reported numbers, but our goal is to underline the existence of these complex cases. In our opinion, these situations, even if seldom, should underline the compulsory longterm, multidisciplinary follow-up of operated patients, with special care and attention to any individual patient by surgical expertise. This emphasises again the necessity of a bariatric centre of excellence that can guarantee a better diagnose and treatment, based on the use of wide, available resources, both professional and material.

\section{Conflict of Interest}

All authors declare that they have no conflicts of interest. No funding was requested or obtained for this study.

\section{Author's Contributions}

Cristian Boru article elaboration, preparation and review, F. de Angelis, Angelo Iossa, Pavlos Antypas, Chiara Ciccioriccio and Pietro Termine collaboration, Prof. G. Silecchia supervising.

\section{References}

1. Angrisani L, Santonicola A, lovino P, Vitiello A, Higa K, Himpens J, et al. IFSO Worldwide Survey 2016: Primary, Endoluminal, and Revisional Procedures. Obes Surg. 2018;28(12):3783-3794.

2. Iossa A, Abdelgawad M, Watkins BM, Silecchia G. Leaks after laparoscopic sleeve gastrectomy: overview of pathogenesis and risk factors. Langenbecks Arch Surg. 2016; 401(6): 757-66.

3. Giuliani A, Romano L, Marchese M, Necozione S, Cianca G, Schietroma M, et al. Gastric leak after laparoscopic sleeve gastrectomy: management with endoscopic double pigtail drainage. A systematic review. Surg Obes Relat Dis. 2019;15(8):1414-1419.

4. Husain F, Jeong IH, Spight D, Wolfe B, Mattar SG. Risk factors for early postoperative complications after bariatric surgery. Ann Surg Treat Res. 2018; 95(2):100-110.

5. Csendes A, Braghetto I, León P, Burgos AM. Management of leaks after laparoscopic sleeve gastrectomy in patients with obesity. J Gastrointest Surg. 2010;14(9):1343-8.

6. Abou Rached A, Basile M, El Masri H. Gastric leaks post sleeve gastrectomy: review of its prevention and management. World $\mathrm{J}$ Gastroenterol. 2014;20(38):13904-10.

7. Al Hajj G, Chemaly R. Fistula Following Laparoscopic Sleeve Gastrectomy: a Proposed Classification and Algorithm for Optimal Management. Obes Surg. 2018;28(3):656-664.

8. Bruzzi M, M'Harzi L, Poghosyan T, El Batti S, Zinzindohoué F, Chevallier JM, et al. Anatomical Relations Between the Esogastric Junction, the Diaphragm, the Pleura, and the Left Lung in Chronic Esogastro-bronchial and/or Esogastro-pleural Fistulas After Sleeve Gastrectomy. Obes Surg. 2019;29(9):2814-2823.

9. Iossa A, Caporilli D, Avallone M, Ciccioriccio MC, Silecchia G. Leak after sleeve gastrectomy: how long do we have to be worried? Minerva Chir. 2018;73(5):522-524.

10. Ben Nun A, Simansky D, Rokah M, Zeitlin N, Golan N, Abu Khalil R, et al. Surgical Treatment of Gastro-Pulmonary Fistula Following Bariatric Surgery: Possible and Safe. World J Surg. 2018;42(6): 1792-1797.

11. Guillaud A, Moszkowicz D, Nedelcu M, Caballero-Caballero A Rebibo L, Reche F, et al. Gastrobronchial fistula: a serious complication of sleeve gastrectomy. Results of a French multicentric study. Obes Surg 2015;25(12):2352-2359. 